\title{
風波のスペクトルの発達 (3)
}

\section{一一有限な吹送距離における風波のスペクトルの標準形*}

光易 恒 ${ }^{* *}$

\section{1. 緒言}

筆者等は，外洋波を精密に測定するため，1971 年に クローバー型波浪計を開発して波浪計測を続けている. 得られた代表的波浪データを解析して, 最近, 海洋波の方 向スペクトルに関する一つの標準形を提案した2). しか しながら，それは方向分布関数の形のみに限られ，周波 数スペクトルの形に関しては, 特に新しい提案は為され なかった，この研究は，前回の研究をおぎうもので， とくに海洋波の周波数スペクトルに関し詳しい検討を行 ない，有限吹送距離の風波のスペクトルに対する一つの 標準形を提案したものである.

海洋波の周波数スペクトルに関しては，古くから多く のスペクトルの形が提案されている．例えば，外洋で十 分発達して吹送距離に無関係となった風波の周波数スペ クトルとしては, 有名な Pierson \& Moskowitz スペク トル3)があり，多くの実測結果はほぼそのスペクトル形 を支持すると報告されている。

一方, 有限吹送距離における風波のスペクトル形とし ては，Bretschneider スペクトル4)を筆者が若干変形した もの ${ }^{5)}$, 筆者のスペクトル ${ }^{5}$ 並びに最近 Hasselmann 等 ${ }^{6}$ が提案した JONSWAP スペクトル等がある。これらは， 大局的には，それぞれ実測結果と一致するが，スペクト ル形の細部に関しては, 必ずしも実測結果をよく表現し ているとは言えない，例えば， Bretschneider スペクト ルや，著者のスペクトル（II 型）は，規格化すれば， Pierson \& Moskowitz スペクトルと同形で，有限吹送距 離の風波にしばしば見られる集中度の大きい周波数スペ クトルを表現することが出来ない.これに対して, JONS. WAP スペクトルは, 北海の沿岸海域で測定された集中 度の大きいスペクトルをもとにして導かれたもので，次 のような形を有している。

$$
\begin{aligned}
& \phi(f)=\alpha g^{2}(2 \pi)^{-4} f^{-5} \exp \left[-\frac{5}{4}\left(\frac{f}{f_{m}}\right)^{-4}\right] \\
& \times \gamma^{\exp \left[-\frac{\left(f / f_{m}-1\right)^{2}}{2 \sigma^{2}}\right]}
\end{aligned}
$$

*この論文は, 最近 Journal of Physical Oceanography に発表 されたもの1を若干書き直したものである.

** 正会員 理博 九州大学教授 応用力学研究所
ただし，

$$
\begin{aligned}
& \alpha=7.6 \times 10^{-2} \tilde{F}^{-0.22} \ldots \ldots \ldots \ldots \ldots \ldots \ldots \ldots \ldots \ldots \\
& U f_{m} / g=3.5 \tilde{F}^{-0.33} \ldots \ldots \ldots \ldots \ldots \ldots \\
& r=3.3, \quad \sigma=\left\{\begin{array}{ll}
0.07, & f \leqq f_{m} \\
0.09, & f>f_{m}
\end{array}\right\}
\end{aligned}
$$

$\tilde{F}=g F / U^{2}, F$ : 吹送距離, $U\left(=U_{10}\right)$ : 海面上 $10 \mathrm{~m}$ の風速.

これは, 式 (1) の下線部の Pierson \& Moskowitz 型 スペクトルのピーク附近を集中度パラメータ $\gamma$ を含む関 数で持ちあげたもので, Pierson \& Moskowitz スペクト ルに比較すると，当然のこと大きな集中度を有してい る. Hasselmann 等は $\gamma$ の実測データが大きく散乱した 值を示したため平均值として上記の值 $r=3.3$ を採用し ているが，筆者等の観測結果によるとスペクトルの集中 度は，無次元吹送距離に依存する傾向がみられた2). 従 って集中度係数 $\gamma$ は, 無次元吹送距離, すなわち波の発 達段階に依存して变化することが予想される．この集中 度係数 $\gamma$ と無次元吹送距離 $\tilde{F}$ との関係を明らかにする ことが本研究の一つの中心を為すものである.

\section{2. 波浪データ}

本研究で使用する波浪データは, 1971 年から 1976 年 にかけて日本周辺の海域において, クローバー型波浪計 を用いて得られたものである. 全部で 67 組の波浪デー タ（それぞれ約 1 時間）のうち，発生域の風波に関する 代表的データ 14 組を選びだして解析を行なった.デー タの選定基準は次の通りである。(1)できるだけ一様な 風が長時間吹き続いている発生域の風波であること, (2) 顕著なうねりが存在していないこと, 従って, (3) スペ クトル形が明暸な一つのピークを有すること.このよう にして選定した波浪データについて, 最少吹送時間を推 定したところ，いづれのデータも最少吹送時間をこえて いることがわかった．したがって，時間的にはほぼ定常 状態に達し, 吹送距離によって, 制限された風波のデー タが選ばれているものと考えられる。図一1 は波および 風の観測点を示し, 観測条件は表一1にまとめて示して ある.

な沶, 風のデータとしては, 最初は観測船上にとりつ 


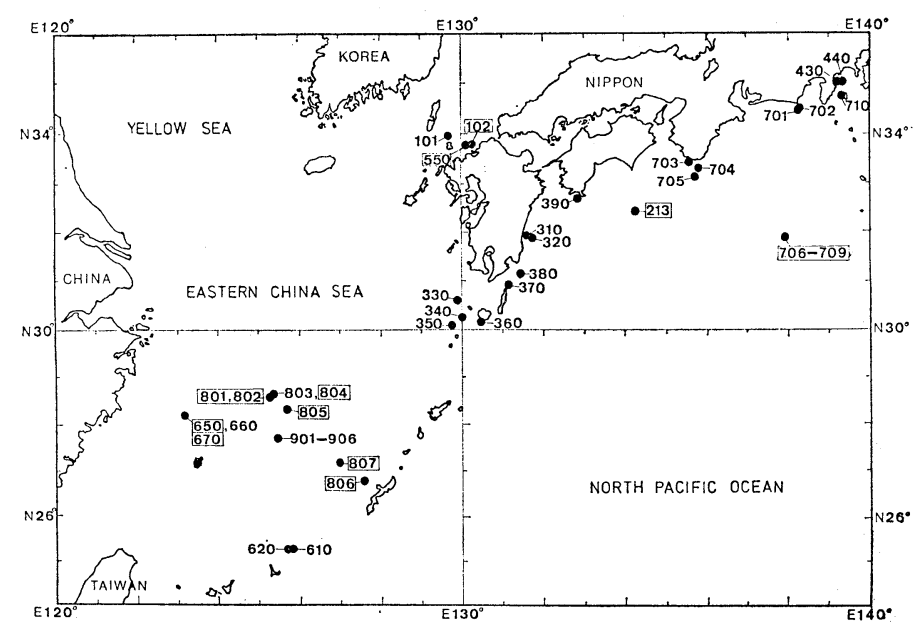

図-1 観測点. 口| 内のデータを今回使用

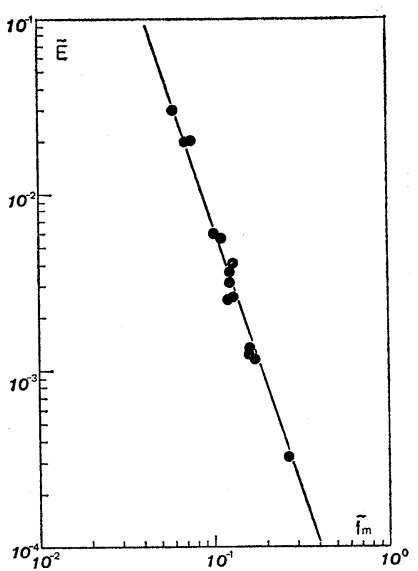

図一2 無次元スペクトルエネルギ - $\tilde{E}$ と無次元ピーク周波 数 $\tilde{f_{m}}$ との関係, 直線は式 (11)
表-1 各種データ. 時刻: 観測開始時刻, 風向 - 風速 $(U)$ : 船上観測值, $U_{e}: f_{m}$ および $E$ からの推 定風速, $\tilde{F}:$ 無次元吹送距離

\begin{tabular}{|c|c|c|c|c|c|c|}
\hline \multirow{2}{*}{ Data No. } & \multirow{2}{*}{ 年月 日 } & \multirow{2}{*}{ 時 刻 } & \multicolumn{3}{|c|}{ 風向特よび風速 } & \multirow{2}{*}{$\frac{\widetilde{F}}{\times 10^{4}}$} \\
\hline & & & 風 向 & $U \mathrm{~m} / \mathrm{s}$ & $U_{e} \mathrm{~m} / \mathrm{s}$ & \\
\hline 213 & $71-12-29$ & $14: 05$ & $\mathrm{NE}$ & 7.0 & 6.5 & 2.94 \\
\hline 550 & '73- 2-19 & $11: 00$ & NNE & 6.5 & 8.2 & 2.93 \\
\hline 651 & '73-5-24 & $14: 18$ & $\mathrm{NE}$ & 9.0 & 8.1 & 1.64 \\
\hline 672 & '76-6- 3 & $15: 50$ & $\mathrm{E}$ & 9.0 & 7.8 & 0.74 \\
\hline 707 & '74-2-13 & $09: 41$ & WNW & 10.0 & 13.2 & 0.46 \\
\hline 708 & " & $10: 08$ & WNW & 10.0 & 11.1 & 0.85 \\
\hline 709 & " & $13: 15$ & WNW & 9.5 & 11.8 & 0.85 \\
\hline 801 & '75- 2-16 & $17: 43$ & $\mathrm{~N}$ & 11.0 & 8.1 & 3.14 \\
\hline 802 & " & $18: 02$ & $\mathrm{~N}$ & 11.0 & 8.8 & 2.27 \\
\hline 804 & '75- 2-19 & $09: 06$ & $\mathrm{~N}$ & 14.0 & 11.1 & 1.20 \\
\hline 805 & " & $15: 21$ & $\mathrm{~N}$ & 14.0 & 10.3 & 1.51 \\
\hline $806^{* 1}$ & '75- 2-23 & $11: 10$ & NW & 7.0 & 6.9 & 6.97 \\
\hline $807^{*}$ & " & $16: 17$ & NNW & 5.5 & 5.3 & 12.70 \\
\hline 102 & '76-10-20 & $08: 05$ & S SW & 12.0 & 10.7 & 0.18 \\
\hline
\end{tabular}

けられた風速計で測定したものを使用した．波浪スペク トルの計算は, 普通の FFT 法で行なわれ, 分解能 3.66 $\times 10^{-2} \mathrm{~Hz}$, Nyquist 周波数 $1.25 \mathrm{~Hz}$, 自由度約 180 の周 波数スペクトルを求め，これをもとにして各種の検討を 行なった.

\section{3. 波浪スペクトルのスケールパラメータ}

有限吹送距離の風波の周波数スペクトルのスケールを きめる重要なパラメータであるスペクトルの全エネルギ 一 $E$, および, スペクトルのピーク周波数 $f_{m}$ は, 風速 $U$ および吹送距離 $F$ との間に次のような比較的単純な
関係を有している。

$$
\begin{aligned}
& \tilde{E}^{1 / 2}=5.24 \times 10^{-4} \tilde{F}^{1 / 2} \\
& \tilde{f}_{m}=2.92 \tilde{F}^{-1 / 3} \quad \ldots \ldots \ldots . . .
\end{aligned}
$$

ただし

$$
\tilde{E}=g^{2} E / U^{4}, \quad \tilde{f}_{m}=U f_{m} / g
$$

上式は，筆者等が以前に導いた式》)に㧍いて，風の摩 擦速度 $u_{*}$ を $U=25 u_{*}$ の近似的関係を用いて海面上 10 $\mathrm{m}$ の風速 $U$ に換算し， $\tilde{F}$ の指数を $0.504 \rightarrow 1 / 2,0.33$ $\rightarrow 1 / 3$ と原式に比べ単純化して求めたものである. Liu ${ }^{8)}$ や Hasselmann 等 ${ }^{6}$ が求めた式も上式に極めて類似した ものである. 式（5）および式（6）から無次元吹送距離 $\tilde{F}$ を消去すると次式が得られる.

$$
\tilde{E} \tilde{f}_{m}^{3}=6.84 \times 10^{-6}
$$

これは, 最初, 鳥羽9),10)により導かれた発達過程にあ る風波に関する“ $2 / 3$ 乗則”と呼ばれる関係式である. この関係式の特徵は, 無次元吹送距離に無関係に成立す る点で, 実際, 無次元吹送距離の非常に大きい場合まで 成立すると言われている Wilson の式（IV 型）をもと にしても上式に類似の関係を導くことができる. 図一2 は，我々が今回使用した波浪スペクトルについて無次元 スケール・パラメータ $\tilde{E}$ と $\tilde{f}_{m}$ との関係を調べたもの で, これょり外洋の非常に大きな吹送距離で発生した風 波のスペクトルについても式 (8) がよく成立することが わかる。

式 (8) は, 普通の次元を有する形で書くと次のように なる。

$$
E f_{m}^{3}=6.84 \times 10^{-6} \mathrm{~g} U
$$

この関係が普遍的なものとすると, 発生域内で測定し た波浪スペクトルの全エネルギー $E$ およびピーク周波 数 $f_{m}$ から逆に発生域の風速 $U$ 它推定する事ができる. このようにして求めた一種の代表風速は $U_{e}$ として表一 
1 に示されている.図-2 からも予想されたことである が， $U_{e}$ と観測船上で計測した風速 $U$ との一致は良好 である、ただし，なかには $30 \%$ 程度のくい違いを示す 場合もある。このくい違いは, 観測船上で計測された風 が必ずしも発生域内の平均的な風を代表しているとは云 えないことを意味するものと思われる. 以後, 波浪スぺ クトルの解析では，Uのかわりに $U_{e}$ をサフィックスな くして発生域の代表風速として使用する. 直接測定した $U$ を使用しても結論は変らないが， $U_{e}$ を使用する事に よりデータの散乱を非常に減少させることが出来た。

\section{4. 標準スペクトルの誘導}

\section{（1）パラメータ $\boldsymbol{\alpha}$ および $\gamma$ の決定}

予備的な検討の結果, 式 (1) で表現される JONSWAP

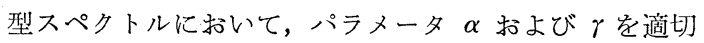
に選べば，実測されたスペクトルとかなり良い一致が得 られることがわかった，そこで今回選び出した 14 例の 風波のスペクトルについて， $\alpha$ および $\gamma$ の值を求めその 特性を調べた。 $\alpha$ および $\gamma$ の決定法は, Hasselmann 等 ${ }^{12)}$ と同様で, 先ず $\alpha$ を次式で決定する.

$$
\begin{aligned}
\alpha= & \left(0.65 f_{m}\right)^{-1} \int_{1.35 f_{m}}^{2 f_{m}}(2 \pi)^{4} f^{5} g^{-2} \\
& \times \exp \left[\frac{5}{4}\left(\frac{f}{f_{m}}\right)^{-4}\right] \phi(f) d f \cdots
\end{aligned}
$$

ここに, $\phi(f)$ は実測された周波数スペクトルである.積 分の下限が $1.35 f_{m}$ にしてあるのは，rの効果が及ばな い範囲とするためである，次にスペクトルのピークにお ける值 $\phi\left(f_{m}\right)$ をもとにして， $\gamma$ の值を次式で決定する。

$$
\gamma=(2 \pi)^{4}\left(\alpha g^{2}\right)^{-1} \phi\left(f_{m}\right) f_{m}^{5} \exp (5 / 4)
$$

ただし， $\alpha$ の值としては式 (10) で求めた值を使用する.

図一3 は，上記の方法で決定した $\alpha$ および $\gamma$ の值を
式（1）に代入して求めたスペクトル形と実測のスペクト ル形とを比較したものの一例である。この眓に示される ように両者の一致は極めて良好である。ただし， $\sigma$ の值 としては, Hasselmann 等6) が求めた值をとのまま使用 し，特に新しい検討は行なわなかった。

\section{(2) パラメータ $\boldsymbol{a}$ および $\gamma$ と $\tilde{f}_{m}$ との関係}

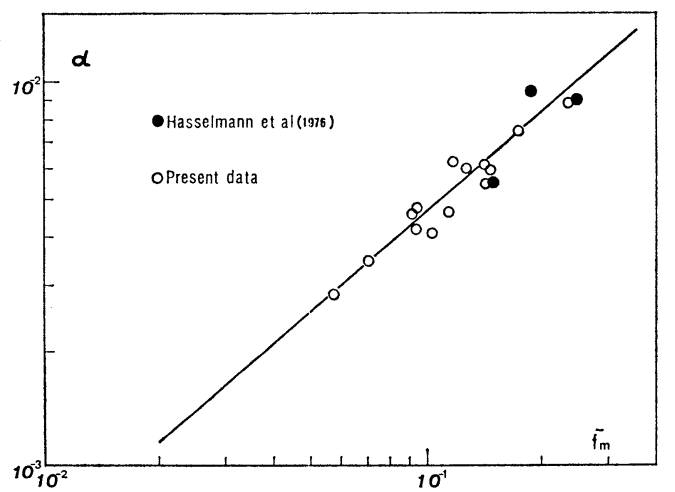

図一4 スケールパラメータ $\alpha$ と無次元ピーク周波数 $\tilde{f_{m}}$ との関係, 直線は式 (12)

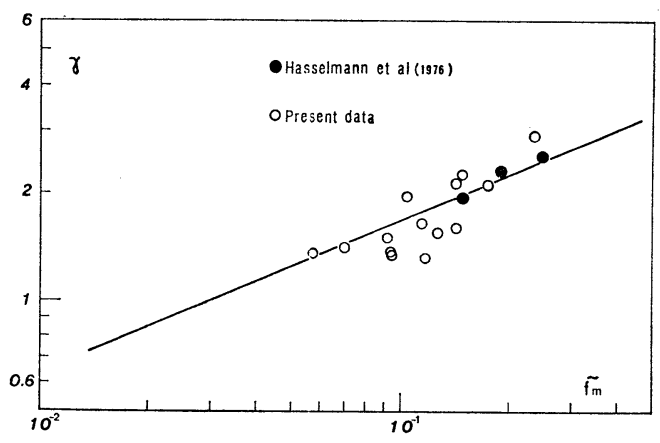

図一5 形状パラメータ $\gamma$ と無次元ピーク周波数 $\tilde{f_{m}}$ との 関係, 直線恃式 (13)

14 例の代表的スペクトルについて求 めたパラメータ $\alpha$ および $\gamma$ の值と無次 元ピーク周波数 $\tilde{f}_{m}\left(\equiv U f_{m} / g\right)$ との関係 を示したものが図一4 および図一5であ る.これより，無次元ピーク周波数 $\tilde{f}_{m}$ とこれらのパラメータとの間には次のよ うな関係があることがわかる。

$$
\begin{aligned}
\alpha & =3.26 \times 10^{-2} \tilde{f}_{m}^{6 / 7} . \\
\gamma & =4.42 \tilde{f}_{m}^{3 / 7} \cdots \cdots \ldots \ldots .
\end{aligned}
$$

Hasselmann 等 $\left.{ }^{12}\right)$ は，彼等のデータを もとにして，式（12）に刘応子る式とし $\tau$,

$$
\alpha=3.3 \times 10^{-2} \tilde{f}_{m}^{2 / 3}
$$

を求めているが，式 (12) は，彼等の データに対してもかなり良い一致を示 †. 


\section{(3) パラメータ $\alpha$ および $\gamma$ と $\tilde{\boldsymbol{F}}$ との関係}

外洋に打いても一つの風域の拡がりは有限であるが, 吹送距離を具体的に決定することは極めて困難である. その理由は，まず風域の境界がはっきりしないこと，た とえ大まかに風域をきめたとしても，その中で必ずしも 風の場が一様ではないことなどの為である. 従って，こ こでは, 天気図や船上で観測した風のデータ等から無次 元吹送距離を決めることをしないで, 次のような方法 で, 一種の有効無次元吹送距離を求めることにした.

湾や湖あるいは陸岸から沖向に風が吹く場合等のよう に, 吹送距離のはっきりした水域で発生した風波のスペ クトルに関しては, 式（5）および式（6）のような非常 に信頼度の高い関係式が得られている. とくに無次元ピ 一ク周波数 $\tilde{f}_{m}$ と無次元吹送距離 $\tilde{F}$ との関係は, かな り精度の高いものである. そこで, 今回外洋で測定した 波浪スペクトルの無次元ピーク周波数 $\tilde{f}_{m}$ の值をもとに して, 式(6)から $f_{m}$ に対応する無次元吹送距離 $\tilde{F}$ を推定 することにした。 このようにして求めた無次元吹送距離 $\tilde{F}$ と，パラメータ $\alpha$ および $\gamma$ との関係を示したものが 図一6 打よび図一7である。ただ，式 (5) 抢よび式 (6) は吹送距離が非常に大きい場合には適用できないのでは ないかと言う心配がある. そこで, 非常に大きい吹送距 離まで適用できると言われている Wilson の式 (IV 型) ${ }^{11)}$

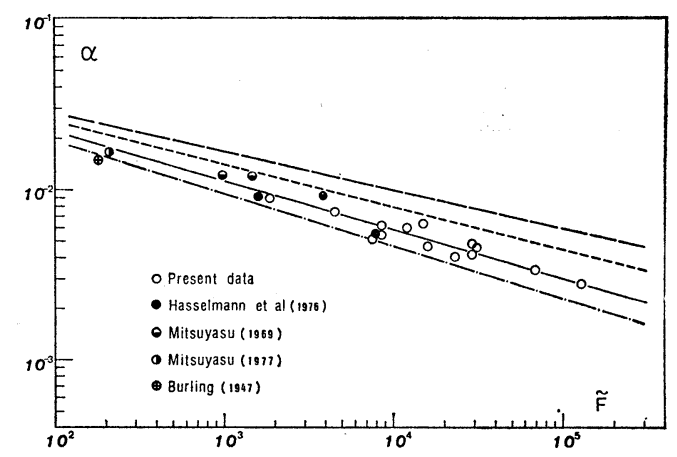

図一6 スケールパラメータ $\alpha$ と無次元吹送距離 $\tilde{F}$ との 関係. 直線は式 (15), 長い破線は式 (19), 短かい 破線は式 (18), 一点鎖線は式 (17)

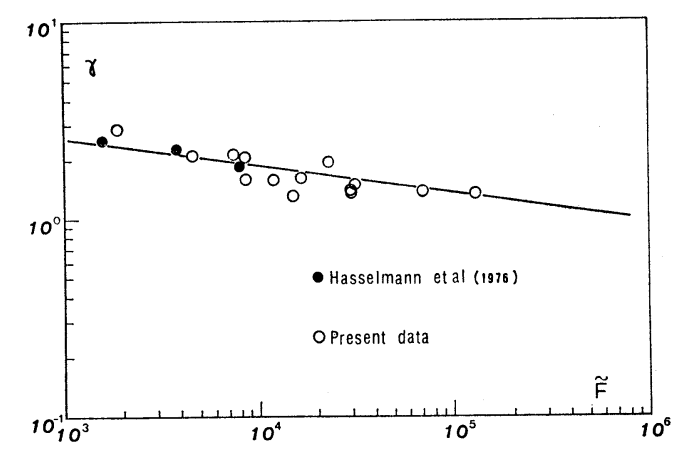

図一7 形状パラメータ $\gamma$ と無次元吹送距離 $\tilde{F}$ との関係. 直線は式 (16)
を使用して， $\tilde{f}_{m}$ から $\tilde{F}$ を推定してみたがデータの散 乱が非常に大きくなって図一6 拉よび 図一7のような規 則的な関係が得られなかった. Wilson の式が導かれた もとのデータを見ると， $\tilde{F} \leqq 10^{5}$ までは近似的に式 (6) を適用することも可能であることがわかったので，式 （6）をもとにして求めた $\tilde{F}$ を最終的に使用した。図一 6 にみられるように今回の $\tilde{F}$ の値は大部分 $10^{5}$ 以下で あるのでこの取扱いはほぼ妥当のものと思われる.

一方，パラメータ $\alpha$ 打よび $\gamma$ と $\tilde{f}_{m}$ との関係を示す 式（12）拉よび式 (13) に, $\tilde{f}_{m}$ と $\tilde{F}$ との関係式 (6) を代入すると次式が得られる。

$$
\begin{aligned}
& \alpha=8.17 \times 10^{-2} \tilde{F}^{-2 / 7} \\
& \gamma=7.0 \tilde{F}^{-1 / 7} \quad \ldots \ldots \ldots . . .
\end{aligned}
$$

これらの式も図一6および図一7に示されているが, 当然予想されるように実測結果との一致は良好である. な打 $\alpha$ に関しては, 次のような各種の関係式が既に提 出されているので，比較のため図一6に一緒に示した。

$$
\begin{aligned}
& \alpha=8.1 \times 10^{-2} \tilde{F}^{-0.308} \quad \text { (Mitsuyasu 197313)) }
\end{aligned}
$$

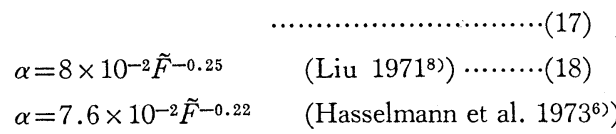

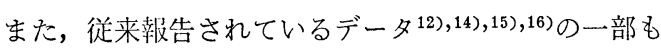
比較のため記入されている。 $\alpha$ に関する上記の実験式は, いずれもあまり大きな差はないが，図一6に示されたデ 一タに関する限り今回提案した式（15）が最もよい一致 を示すことがわかる。

\section{5. 結果および討論}

以上の結果をとりまとめると, 次のようになる. 発達過 程にある有限吹送距離の風波の周波数スペクトル $\phi(f)$ の主要部 $\left(0.7<f / f_{m} \leq 2\right)$ は, 近似的に次式で表現され る.

$$
\begin{aligned}
\phi(f)= & \alpha g^{2}(2 \pi)^{-4} \exp \left[-\frac{5}{4}\left(\frac{f}{f_{m}}\right)^{-4}\right] \\
& \times \gamma^{\exp \left[-\left(f / f_{m}-1\right)^{2} / 2 \sigma^{2}\right]}
\end{aligned}
$$

ただし，

$$
\begin{aligned}
& \alpha=3.26 \times 10^{-2} \tilde{f}_{m}^{6 / 7} \text { あるいは } \alpha=8.17 \times 10^{-2} \tilde{F}^{-2 / 7} \\
& \tilde{f}_{m}\left(\equiv\left(U f_{m} / g\right)=2.92 \tilde{F}^{-1 / 3}\right. \text {, } \\
& \gamma=4.42 \tilde{f}_{m}^{3 / 7} \text { あるいは } \gamma=7.0 \tilde{F}^{-1 / 7} \\
& \sigma=\left\{\begin{array}{ll}
0.07 & f \leqq f_{m} \\
0.09 & f>f_{m}
\end{array}\right\}
\end{aligned}
$$

これが今回提案する有限吹送距離の風波に対する周波 数スペクトルの標準形である.

ただ，少し注意して扮かなければならない事は，上記 のスペクトル形は，外洋で計測された波浪データのみを 使用して導かれた事である. このため無次元吹送距離 $\tilde{F}$ の範囲は, $10^{3} \sim 10^{5}$ と比較的大きい所にある. 湾内や沿 
岸海域等で発生した無次元吹送距離の小さい $\left(\tilde{F}<10^{3}\right)$ 風波のスペクトルに対しても，このスペクトル形が適用 できるかどうかは今後検討の余地がある. Hasselmann 等6)が最初報告したデータ $\left(10^{2}<\tilde{F}<10^{4}\right)$ や， Ewing ${ }^{17)}$ が最近報告したデータ $\left(0.2<\tilde{f}_{m}<0.4\right)$ では $\gamma$ の值は非 常に散乱しているが平均的にかなり大きな值を示し，今 回提案した式と必ずしもよく合わない，㷧因として は, 波の測定法, スペクトルの計算法抢よび精度, でき るだけ理想的な条件で得られた波浪データの選別法，等 色々考えられるが，現在の所はっきりしない，ただ，実 験室の風波のスペクトルならびに筆者等が, 沿岸海域で 測定したスペクトルのデータと比較すると彼等の報告し ているとの值は，少し大きすぎるように思われる。

謝辞：今回使用した波浪データは, 応用力学研究所 が 1971 年から 1973 年にかけて実施した大型共同研究 「海洋波の計測法の開発研究」で得られたものの一部な らびに国際共同研究 AMTEX (気団変質観測) に参加し て得られたものの一部である。これらの共同研究におい て援助を受けた非常に多くの方々に対し心から感謝の意 を表わします。な押，この研究のとりまとめは，文部省 科定研究費「自然災害特別研究」によって行なわれたも のであることを附記し謝意を表わします。

\section{参考文 献}

1) Mitsuyasu, H. et al.: J. Phys. Oceanogr., Vol. 10, pp. 286 296, 1980.

2) Mitsuyasu, H. et al.: J. Phys. Oceanogr., Vol. 5, pp. $750 \sim 760,1975$.

3) Pierson, W. J. and L. Moskowitz: J. Geophys. Res., Vol. 69, pp. 5181 5190, 1964.

4) Bretschneider, C. L.: Fundamental in Ocean Engineering, Part 7, Ocean Industry, Feb., pp. 40 46, 1968.

5）光易 恒：第 17 回海岸工学講演会論文集, pp. 1 7, 1970 .

6) Hasselmann, K. et al.: Dtsch. Hydrogr. Zeit. A (8), 95 p., 1973.

7) Mitsuyasu, H.: Rep. Res. Inst. Appl. Mech., Kyushu Univ., Vol. 16, pp. 459 482, 1968.

8) Liu, P. C.: J. Phys. Oceanogr., Vol. 1, pp. 249 257, 1971.

9) Toba, Y.: J. Oceanogr. Soc. Japan, Vol. 28, pp. 109 120, 1972.

10) Toba, Y.: J. Phys. Oceanogr., Voí. 8, pp. 494 507, 1978.

11) Wilson, B. W.: Dtsch. Hydrogr. Zeit., Vol. 18, pp. $114 \sim 130,1965$.

12) Hasselmann, K. et al.; J. Phys. Oceanogr., Vol. 6, pp. 200 208, 1976.

13) Mitsuyasu, H.: Rep. Res. Inst. Appl. Mech., Kyushu Univ., Vol. 20, pp. 37 53, 1973.

14) Mitsuyasu, H.: Rep. Res. Inst. Appl. Mech., Kyushu Univ., Vol. 17, pp. 235 248, 1969.

15) Mitsuyasu, H.: J. Phys. Oceanogr., Vol. 7, pp. 882 891, 1977.

16) Burling, R. W.: Dtsch. Hydrogr. Zeit., Vol. 12, pp. 45 64, 1959.

17) Ewing, J. A.; Estuarine and Coastal Marine Science (Unpublished). 